\title{
MicroRNA: a novel implication for damage and protection against ionizing radiation
}

\author{
Yonglin Chen ${ }^{1,2} \cdot$ Jian Cui ${ }^{1,2} \cdot$ Yaqi Gong ${ }^{1,2} \cdot$ Shuang Wei ${ }^{1,2} \cdot$ Yuanyun Wei ${ }^{1,2} \cdot$ Lan $_{\mathrm{Yi}^{1,2}}{ }^{10}$
}

Received: 26 October 2020 / Accepted: 12 January 2021 / Published online: 3 February 2021

(C) The Author(s), under exclusive licence to Springer-Verlag GmbH, DE part of Springer Nature 2021

\begin{abstract}
Ionizing radiation (IR) is a form of high energy. It poses a serious threat to organisms, but radiotherapy is a key therapeutic strategy for various cancers. It is significant to reduce radiation injury but maximize the effect of radiotherapy. MicroRNAs (miRNAs) are posttranscriptionally regulatory factors involved in cellular radioresponse. In this review, we show how miRNAs regulate important genes on cellular response to IR-induced damage and how miRNAs participate in IR-induced carcinogenesis. Additionally, we summarize the experimental and clinical evidence for miRNA involvement in radiotherapy and discuss their potential for improvement of radiotherapy. Finally, we highlight the role that miRNAs play in accident exposure to IR or radiotherapy as predictive biomarker. miRNA therapeutics have shown great perspective in radiobiology; miRNA may become a novel strategy for damage and protection against IR.
\end{abstract}

Keywords Ionizing radiation $\cdot$ MicroRNA $\cdot$ Cellular response $\cdot$ Cancer $\cdot$ Radiotherapy $\cdot$ Biomarker

$\begin{array}{ll}\text { Abbreviations } \\ \text { ATM } & \text { ataxia-telangiectasia mutated } \\ \text { AKT } & \text { RAC-alpha serine/threonine-protein kinase } \\ \text { A549 } & \text { a type of non-small cell lung cancer cell } \\ \text { BAX } & \text { Bcl-2-like protein } 4 \\ \text { BCL-2 } & \text { B cell lymphoma } 2 \\ \text { CDC25A } & \text { cell division cycle 25A } \\ \text { CDK } & \text { cyclin-dependent kinase } \\ \text { CHK } & \text { checkpoint kinase } \\ \text { c-Myc } & \text { Myc proto-oncogene protein } \\ \text { DSB } & \text { DNA strand break } \\ \text { EGFR } & \text { epidermal growth factor receptor } \\ \text { EMT } & \text { epithelial-to-mesenchymal transition } \\ \text { HIF-1 } \alpha & \text { hypoxia-inducible factor 1- } \alpha\end{array}$

Responsible Editor: Georg Steinhauser

Lan Yi

yilanoky@126.com

1 Hengyang Medical College, Institute of Cytology and Genetics, The Hengyang Key Laboratory of Cellular Stress Biology, University of South China, Hengyang 421001, Hunan Province, People's Republic of China

2 Hunan Province Cooperative Innovation Center for Molecular Target New Drug Study, Hengyang 421001, Hunan Province, People's Republic of China

$\begin{array}{ll}\text { HR } & \text { homologous recombination } \\ \text { IR } & \text { ionizing radiation } \\ \text { miRNA } & \text { MicroRNA } \\ \text { mTOR } & \text { mechanistic target of rapamycin kinase } \\ \text { NHEJ } & \text { non-homologous end joining } \\ \text { NSCLC } & \text { non-small cell lung cancer } \\ \text { PTEN } & \text { phosphatase and tensin homolog } \\ \text { PI3K } & \text { phosphoinositide 3-kinase } \\ \text { P21 } & \text { cyclin-dependent kinase inhibitor 1A } \\ \text { P53 } & \text { cellular tumor antigen p53 } \\ \text { RAD51 } & \text { DNA repair protein RAD51 homolog 1 } \\ \text { ROS } & \text { reactive oxygen species } \\ \text { ZEB1 } & \text { zinc finger E-box-binding homeobox 1 }\end{array}$

\section{Introduction}

Ionizing radiation (IR) is a form of high energy consisting of alpha and beta particles as well as electromagnetic energy radiation including gamma and $\mathrm{X}$ rays. It acts through high energy physics via damaging factors by producing intermediate ions and free radicals that damage the chemical structure of DNA with DNA strand breaks (DSBs) as the most lethal injury (Carter et al. 2019; Smith et al. 2017). IR-induced DSBs trigger DNA damage repair mechanisms among which nonhomologous end joining (NHEJ) and homologous 
recombination (HR) are the two main pathways (Mueck et al. 2017). When DNA damages caused by IR are over the cellular ability to repair, improper DNA repair will lead to cell death. (Shimizu et al. 2015). At the organism level, high-dose radiation causes acute radiation sickness and severe diseases such as leukemia, thyroid, breast, and skin cancers, and cataracts (Douple et al. 2011; Hamada and Sato 2016; Mettler Jr. et al. 2007). Low-dose radiation does not have severe effects, but long-term exposure to low-dose radiation leads to an increased risk of leukemia, lymphoma, and abnormalities in the central nervous system (Spycher et al. 2015). In the clinic, radiotherapy has been widely used for medical diagnostics and cancerrelated therapy, especially for the treatment of localized solid cancers (Schaue and McBride 2015). However, the effect of radiotherapy is generally limited by radioresistant cancer cells (Peters et al. 1982). Furthermore, many patients experience some adverse physiological reactions during radiotherapy, such as nausea and/or vomiting (Grabenbauer and Holger 2016). Some radiation-induced diseases, such as pneumonia, mucositis, and cardiac disease, are also accompanied by radiotherapy (Atkins et al. 2019; Grabenbauer and Holger 2016; Sato et al. 2018). Therefore, reducing the injury of accidental exposure to radiation and maximizing the effects of radiotherapy on tumors while minimizing radiotoxicity to patients are the ultimate aims of researchers.

Over the past decades, studies ofmicroRNA (miRNA) have revealed a strong association with the radiation response in various cell lines, tissues, and animal models, which provide new insights to avoid the hazards of IR. miRNAs, a class of small non-coding RNAs (about $22 \mathrm{nt}$ ), are negative gene regulators at the posttranscriptional level through binding to the 3 '-untranslated regions of target mRNAs to inhibit expression (Bartel 2004). miRNAs regulate the cellular response to IR by participating in multiple pathways involved in DNA repair, cell cycle checkpoints, apoptosis, autophagy, and oxidative stress (Gandellini et al. 2014). Accumulating studies have shown that dysregulation of some single miRNAs facilitates the progression of adverse reactions induced by radiation or promotes sensitivity to radiation (Tian et al. 2019; Yan et al. 2018). There is increasing interest for researchers to investigate functional relationships between miRNA expression and IR.

\section{IR alters miRNA expression}

Through the development of high throughput sequencing and miRNA databases, many research groups have explored the associations of specific miRNAs with cellular responses to radiation. Their reports have demonstrated that radiation changes miRNA expression significantly. In the serum of baboons, miR-212 showed 48-77-fold upregulation upon 2.5 and 5 Gy irradiation, while miR-342-3p showed 10-fold downregulation (Port et al. 2018, 2016). In the blood of irradiated mice, several members of the miR-17 family (miR-17$5 p,-106 b-5 p,-20 a-5 p$, and $-20 b-5 p)$ suppressed the response to 2 Gy radiation (Aryankalayil et al. 2018). miR-375-3p was increased significantly in mouse serum after whole body exposure to 7 Gy of X-ray (Chiba et al. 2018). At the organ level, miR-146a-5p was downregulated and miR-467b-5p was upregulated in the IR-exposed mouse thymus (Chen et al. 2016). miR-34c/138 was downregulated, and members of the Let-7 family were upregulated in mice testes upon carbon ion irradiation (He et al. 2018). miR-3037b-5p/34a-5p were upregulated in the irradiated mouse liver after total body irradiation (Lu et al. 2016). In radiotherapy, IR increased the serum miR34a level in 44 women with breast cancer (Halimi et al. 2016). miR-29a-3p and miR-150-5p were decreased with increasing radiation doses in lung cancer patients (Dinh et al. 2016). In prostate cancer patients, two miRNAs, namely hsa-let-7a-5p and hsa-miR-21a-5p, were upregulated by irradiation (Malla et al. 2018). Taken together, these results indicate that miRNA changes in response to radiation are dependent on the dose, cell type, and disease. Furthermore, in normal thyroid cells (FRTL-5 CL2), miR-10b-5p/199a-3p were downregulated at 1-h post-irradiation and then upregulated after $6 \mathrm{~h}$, which finally returned to the unexposed control expression level at 24$\mathrm{h}$ post-irradiation (Penha et al. 2018). This study indicated that radiation-modulated miRNAs are transient and may have different temporal expression patterns. Thus far, the mechanism underlying how ionizing radiation regulates miRNA expression remains largely unknown and further in-depth studies are needed.

\section{miRNAs regulate important genes related to the cellular radioresponse}

miRNAs strongly affect the cellular radioresponse via regulation of vital genes involved in DNA damage repair, cell cycle checkpoints, and apoptosis (Fig. 1). IR destroys DNA structures with ionizing events and the generation of free radicals and reactive oxygen species (ROS). Some miRNAs such as miR-139-5p induced by IRexacerbated accumulation of DNA damage by targeting ROS defense-related gene methionine adenosyltransferase 2 (MAT2A) (Pajic et al. 2018). The first step in triggering the DNA damage response is sensing the DNA damages by ataxia-telangiectasia mutated (ATM) and ataxia-telangiectasia (ATR) that activate cyclin-dependent kinase (CHK) and subsequently triggers the signaling pathway leading to checkpoint activation and DNA repair (Awasthi et al. 2016). Cell division cycle 25A (CDC25A) accelerates entry into $\mathrm{S}$ phase and promotes mitotic events by activating cyclin-dependent kinase (CDK)-cyclin complexes, while CHK mediates $\mathrm{S}$ and $\mathrm{G} 2$ phase arrest through phosphorylation of CDC25A, which causes its degradation (Boutros et al. 2007). In this process, many miRNAs repress cell growth by 


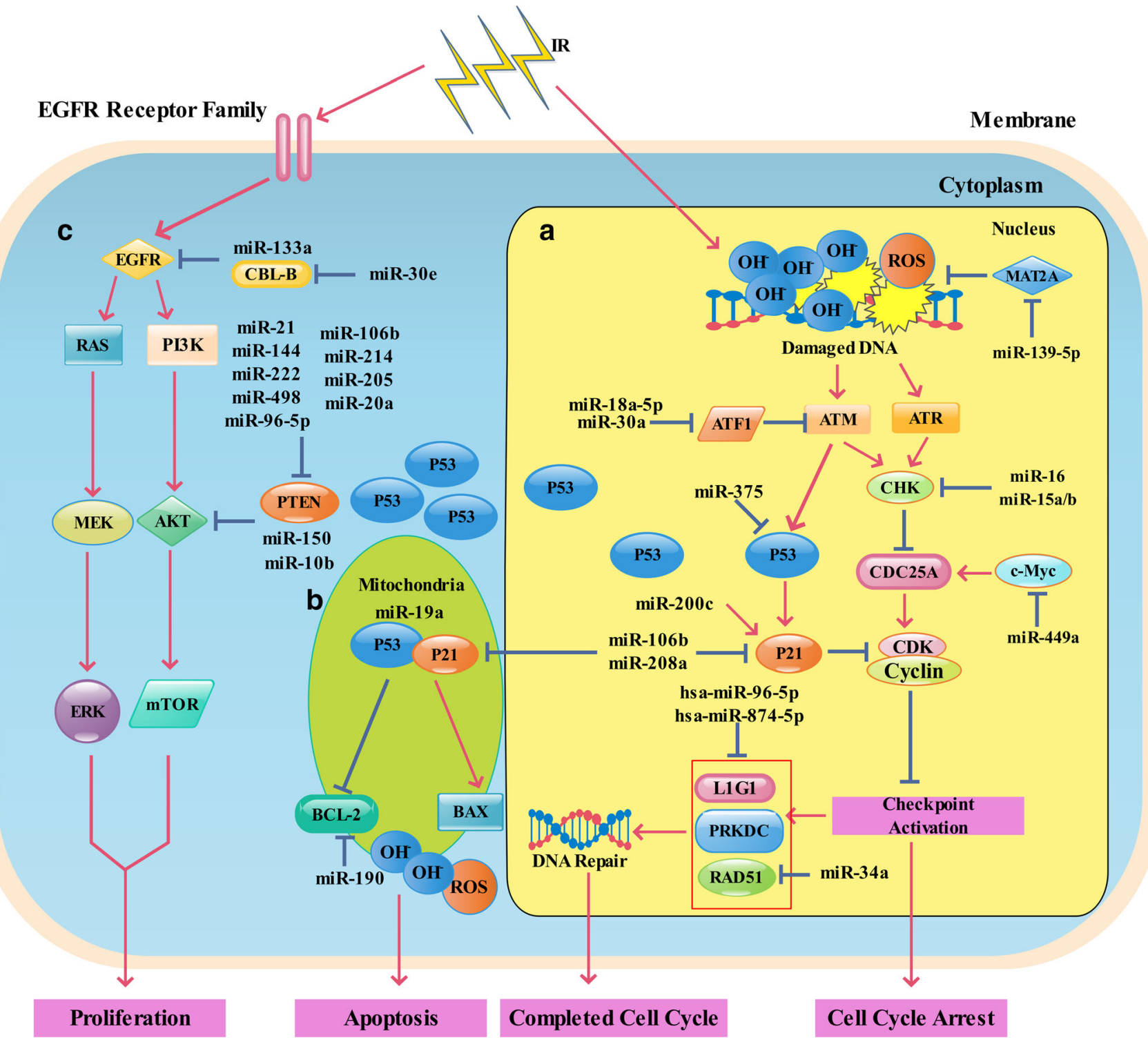

Fig. 1 miRNAs participate in the regulation of key genes related to cellular response to IR. a IR-induced damaged DNA is sensed by ATM and ATR. Both of them can trigger activation of CHK and initiate the signaling pathway, leading to Checkpoint activation and DNA repair. Actived CHK degrades CDC25A, and consequently impairs CDK/ Cyclin complex that is necessary for transform from $\mathrm{G} 1$ to $\mathrm{S}$ phase and $\mathrm{G} 2$ to $\mathrm{M}$ phase. What is more, ATM/P53/P21 is another vital pathway to inhibit cell cycle progress. P53 can be activated by ATM with phosphorylation and subsequently stimulates expression of $\mathrm{P} 21$, which is an inhibitor of CDK/Cyclin complex. After activation of checkpoint, if DNA repair goes smoothly, the cell cycle goes on. b ATM-activated P53

downregulating these factors. miR-30e blocked IR-induced G2/M checkpoint arrest with increased ATM by targeting activating transcription factor 1 (ATF1) that phosphorylates ATM (Guo et al. 2017). Overexpression of miR-18a-5p inhibited the growth of non-small lung cancer xenografts (A549) after radiation exposure by downregulating ATM (Chen et al. 2018). The miR-15 family (miR-15a/b, -16) released radiation-induced G2 arrest and suppressed cell aggregating in cytoplasm cooperates with P21 and promotes mitochondria to produce reactive oxygen species via inhibition of anti-apoptotic gene BCL-2 and enhance pro-apoptotic gene BAX, ultimately leading to apoptosis. $\mathbf{c}$ IR is able to activate EGFR and EGFR initiates PI3K/AKT pathway and MAPK pathway to promote cell proliferation. PTEN is an important antagonist of AKT. Its inhibition is closely related to activation of PI3K/AKT pathway and cell proliferation. miRNAs have a great effect on cellular response to IR via negative regulation of genes associated with proliferation, apoptosis, DNA repair, and cell cycle. More information depicted in text

proliferation after irradiation by targeting CHK1 and downregulating B cell lymphoma 2 (BCL-2) in breast cancer cells (Mei et al. 2015). miR-449a enhanced radiation-induced G2/ $\mathrm{M}$ phase arrest by downregulating Myc proto-oncogene protein (c-Myc) and cell cycle regulator CDC25A in prostate cancer cells (Mao et al. 2016). c-Myc stimulates CDC25A expression, and $\mathrm{CDC} 25 \mathrm{~A}$ accelerates entry into $\mathrm{S}$ phase and promotes mitotic events by activating $\mathrm{CDK}$-cyclin complexes 
(Boutros et al. 2007; Galaktionov et al. 1996). Furthermore, ATM/cellular tumor antigen p53 (P53)/cyclin-dependent kinase inhibitor 1A (P21) is another important pathway that activates cell cycle checkpoints. CHK2 activated by ATM phosphorylates P53. The latter accumulates in the nucleus and stimulates downstream P21 expression (Jin and Oh 2019). miR-375 promoted radiosensitivity of HR-HPV (+) cancer cells by decreasing P53 degradation, thereby increasing radiation-induced apoptosis (Song et al. 2015). miR-200c induced $\mathrm{G} 2 / \mathrm{M}$ and sub-G1 arrest, decreased the S phase rate in esophageal cancer cells with reduced Cyclin B1 and CDK1, and increased P21 (Zheng et al. 2017). However, miRNAs whose target gene is P21 determine a very different cellular fate. miR-106b enhanced the tumor-initiating cell capacity by directly targeting PTEN and P21 (Zheng et al. 2015b). Radiation-induced miR-208a increased the proliferation and radioresistance of human lung cancer cells by targeting P21 and activating the AKT/mTOR pathway (Tang et al. 2016).

When DNA damages caused by IR activate cell cycle checkpoints, broken DNA strands are repaired mainly by two mechanisms: NHEJ and HR pathway. If DNA damage can be repaired completely, the cell cycle continues, or the cell dies due to apoptosis or mitotic catastrophe (Maier et al. 2016). Overexpression of hsa-miR-96-5p and hsa-miR-874$3 p$ combining with IR decreased the survival of non-small cell lung cancer (NSCLC) cells to a higher extent than that exerted by radiation alone by targeting DNA repair protein RAD51 homolog 1 (RAD51) and DNA-dependent protein kinase catalytic subunit (PRKDC) and leucine-rich repeats and immunoglobulin-like domain protein 1 (L1G1) that are genes involved in HR and NHEJ pathways (Piotto et al. 2018). miR34a suppressed DNA repair after irradiation and promoted apoptosis of NSCLC cells by targeting RAD51 (Cortez et al. 2015). ATM activates P53 aggregates in the cytoplasm to inhibit anti-apoptotic gene BCL-2, releases pro-apoptotic gene Bcl-2-like protein 4 (BAX) with P21, then enhances the ability of mitochondria to produce ROS (Dogu and Díaz 2009; Kim et al. 2017). Consistent with these findings, miR208a, whose target gene was P21, upregulated BCL-2 while downregulating BAX (Tang et al. 2016). miR-19a was related to proliferation and metastasis of cervical cancer cells, but inhibition of miR-19a reduces cell proliferation andincreased apoptosis with upregulation of BAX and downregulation of BCL-2 (Wang et al. 2017). A low level of miR$190 \mathrm{~b}$ and high expression of BCL-2 were found in radioresistant gastric cells, whereas miR-190b mimics reduced the survival rate of gastric cells and sensitized the cells to radiation by downregulation of BCL-2 (Wang and Qiao 2017).

In response to IR, the epidermal growth factor receptor (EGFR) family in the membrane activates and EGFR functions as an anti-apoptotic factor, especially in heterodimers with receptor tyrosine-protein kinase erbB-2 (ERBB2) (Maier et al. 2016).
It has been reported that IR-inducible miR-30e promoted glioma cell invasion through EGFR stabilization by directly targeting casitas B-lineage lymphoma B (CBL-B), which increased EGFR abundance (Kwak et al. 2015). EGFR activates the phosphoinositide 3-kinase (PI3K)/protein kinase B (AKT)/ mechanistic target of rapamycin (mTOR) pathway to prevent apoptosis and promote cell proliferation (Fig. 1) (Krieger et al. 2019; Lee et al. 2018). Phosphatase and tensin homolog (PTEN) is an important antagonist of AKT (Zheng et al. 2016). Many miRNAs have been reported to downregulate PTEN to activate the PI3K/AKT pathway, which enhances radioresistance with increased proliferation (Fig. 1) (Duan et al. 2019; Pan et al. 2017; Vahabi et al. 2019; Wu et al. 2018b; Yu et al. 2015a; Zhang and Zhang 2017; Zhang et al. 2015c; Zhou et al. 2015a). miR-150 promoted IR-induced apoptosis in NK/T cell lymphoma cells by directly targeting AKT1 and AKT2 (Wu et al. 2018a), while miR-10b weakened the IR-induced inhibitory effect on reproduction of glioblastoma by targeting p-AKT (Zhen et al. 2016). The mitogen-activated protein kinase (MAPK) pathway activated by EGFR is another pathway that contributes to cell proliferation (Fig. 1). miR-133a was upregulated in radiosensitive patients with esophageal cancer and increased cancer cell apoptosis by targeting EGFR with reduced phosphorylated mitogen-activated protein kinase 1/2 (MEK1/2) and phosphorylated extracellular signal regulated kinase $1 / 2$ (ERK1/2) expression (Yang et al. 2017).

miRNAs have been reported to participate in the regulatory network of radiation autophagy (Fig. 2). Song et al. (2016) have reported that exosomal miR-7-5p was upregulated in human bronchial epithelial cells (BFP2D) after irradiation, which induced autophagy by targeting EGFR with activation of the AKT/mTOR pathway and upregulation of Beclin-1. Cai et al. (2017) found that exosomal miR-7 induced bystander autophagy in lungs after brain irradiation via inhibition of BCL-2. Unlike these miRNAs that induce autophagy, some miRNAs perform converse function about it. For example, miR-216a and miR-17$5 \mathrm{p}$ were both downregulated after irradiation. Downregulation of miR-216a and miR-17-5p upregulated the expression of Beclin1 as a critical autophagic gene, which led to autophagy (Hou et al. 2017; Zhang et al. 2015b).

\section{miRNAs participate in radiation-induced carcinogenesis}

Radiation carcinogenesis is regarded as a fateful long-term effect of exposure to radiation. Increasing data have demonstrated alterations of miRNAs in different types of cancer induced by radiation, which indicates their important role in radiation carcinogenesis (Cui et al. 2014; Iizuka et al. 2012; Kim et al. 2016). Bueno et al. (2008) have reported that a chromosomal region (chromosome 12 position 107.4$113.7 \mathrm{Mb}$ enriched with miRNAs) was frequently lost in irradiated $\mathrm{T}$ cell lymphomas. In a further study, they found that 


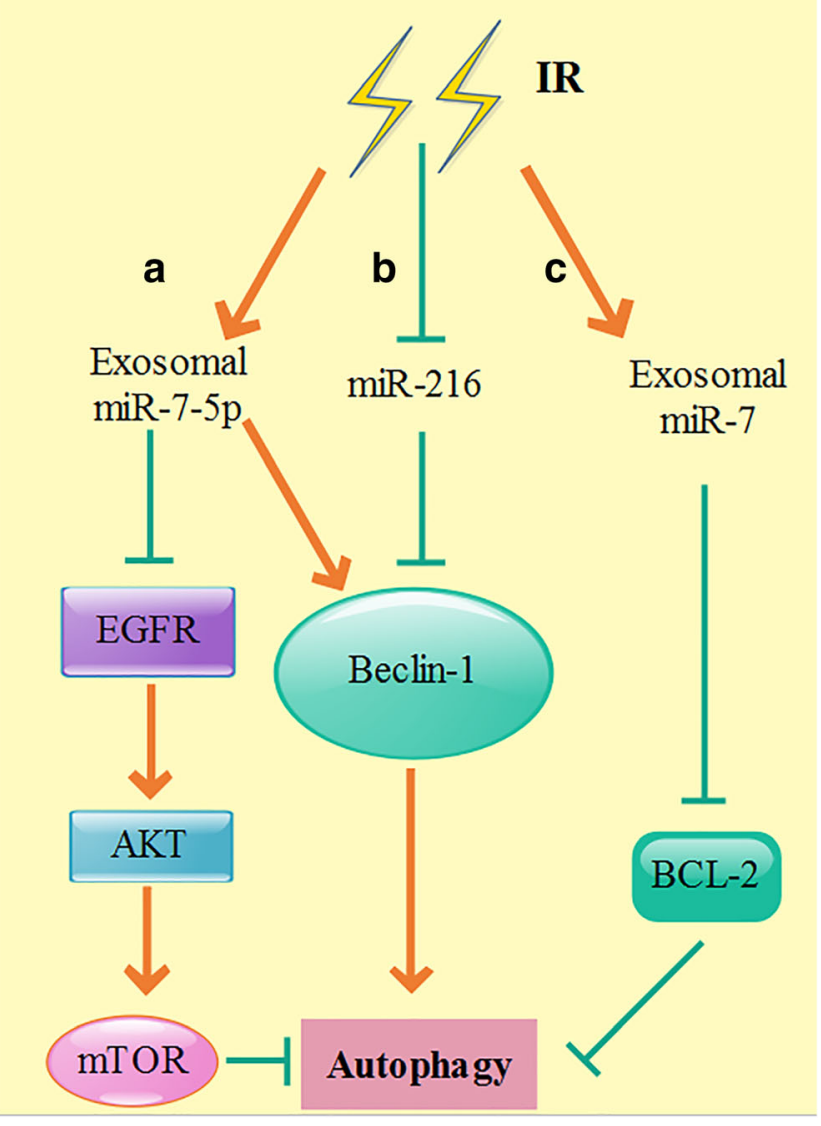

Fig. 2 IR induces autophagy through alternation of miRNAs. a Exosomal miR-7-5p upregulated by IR targets EGFR and inactives AKT/mTOR pathway that localizes at downstream of EGFR, leading to process of autophagy. b Beclin-1 as a critical autophagic gene, its overexpression regulated by miRNAs results in autophagy. c Exosomal miR-7 increased by IR promotes autophagy by targeting BCL-2

miR-203 located in this $7 \mathrm{Mb}$ region was silenced significantly by additional hypermethylation. Silencing of miR-203 enhanced expression of Abelson murine leukemia viral oncogene homolog 1 (ABL1) and break-point cluster region (BCR)-ABL1 that are classic oncogenes extensively characterized in hematopoietic malignancies and both chronic myelogenous and B cell leukemias, respectively. In radiationinduced thymic lymphoma, one of the most classic models of radiation-induced carcinoma, miR-467 was identified as a new oncomiRNA and its overexpression facilitated tumorigenesis by targeting pro-apoptotic gene tumor necrosis factor receptor superfamily member 6 (FAX) and BAX (Gao et al. 2015), while miR-143 was downregulated and its downregulation also promoted radiation-induced thymic lymphoma by targeting B7 homolog 1 (B7H1), which may allow cancer cells to evade the host immune system (Zhao et al. 2017). Additionally, miR-21, the star oncomiRNA, has been reported to perform its pro-tumor function in conjunction with radiation (Liu et al. 2011). Zhang et al. (2019) had identified a functional link between IR-inducible miR-21 and angiogenesis that promotes metastasis, invasion and growth of tumors. Ionizing radiation induced miR-21 overexpression, which in turn downregulated expression of PTEN and finally induced angiogenesis via increased vascular endothelial growth factor A (VEGF) and HIF- $1 \alpha$ expression through the PI3K/AKT pathway. This study further verified miR-21 as potent factor in radiation carcinogenesis. IR is capable of amplifying oncomiRNAs that inactivate tumor suppressor genes or restraining anti-oncomiRNAs that target oncogenes, which triggers carcinoma formation (Fig. 3). These studies support the mechanism through which IR acts as a carcinogen to provoke the onset of carcinogenesis from the aspect of miRNA and provide a new insight for radiation oncology.

\section{Modulation of miRNA contributes to improvement of radiosensitivity in tumors}

A large number of studies have focused on the role of miRNAs in response to IR in various tumor types (details in Table 1). The findings reveal the association between miRNAs and radiotherapy and possible new treatments for cancer. Especially in the case of inoperable carcinomas such as melanomas, sarcomas, and some tumors with radioresistance (He et al. 2017a; Yang et al. 2018), the importance of targeting modulation of specific miRNAs as a strategy to improve the effect of radiotherapy is evident (Korpela et al. 2015). Members of the Let-7 family and miR-34a have been identified as tumor growth suppressors (Li et al. 2016; Sun et al. 2016). Overexpression of Let$7 \mathrm{~b}$ sensitized uveal melanoma cells to IR by targeting cyclin D1 (Zhou et al. 2015b). miR-34a directlybound to the 3'-untranslated region of RAD51 involved in DNA double-strand break repair and sensitized lung tumors to radiation (Cortez et al. 2015). Conversely, downregulation of miR-21, which was considered as an oncomiRNA that contributed to angiogenesis, radiosensitized non-small cell lung cancer by increasing PTEN expression (Tang et al. 2019; Zhang et al. 2015a). In addition to regulating pathways related to DNA repair and apoptosis, miRNAs regulate the tumor response to radiation via other mechanisms. miR-449a enhanced radiosensitivity of A549 cells by suppressing lactate dehydrogenase A (LDHA) and glycolysis that is a primitive metabolic pathway easily exploited by cancer cells for energy to grow and spread (Birts et al. 2020; Li et al. 2018c). miR-129-5p repressed radiationinduced autophagy by targeting high-mobility group box-1 protein 1 (HNGB1) in breast cancer, while autophagy was thought to contribute to radioresistance because of its capability to remove ROS and inhibit apoptosis ( $\mathrm{Li}$ et al. 2018b; Luo et al. 2015). miR-875-5p had the potential to counteract epithelial-tomesenchymal transition (EMT) to circumvent radiation resistance in prostate cancer by inhibition of the EGFR-zinc finger E-box-binding homeobox 1 (ZEB1) axis (El Bezawy et al. 
Fig. 3 IR-induced modulation of miRNAs initials carcinogenesis. a IR destroys structure of chromosome 12 and causes silence of miR-203 to facilitate carcinogenesis with enhancing expression of oncogene ABL1 and ABL1-BCR. b IR increases expression of miR-467 and suppresses expression of miR-143. miR-467 targets proapoptotic gene FAX and BAX that inhibit thymic lymphoma, while target gene of miR-143, B7H1, promotes this disease. c IR-induced miR-21 activates PI3K/AKT pathway by targeting PTEN, then increases VEGF and HIF- $1 \alpha$ level to promote angiogenesis

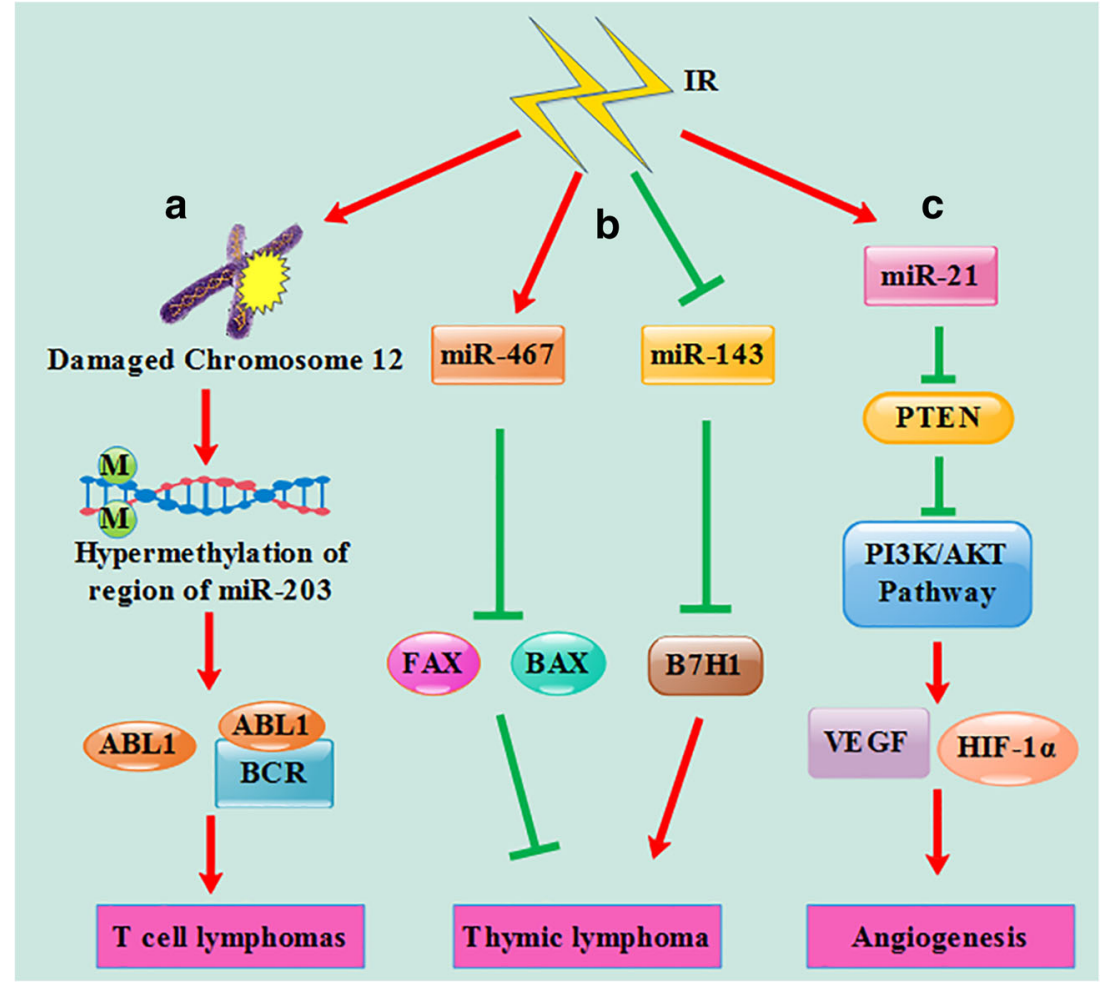

2017). miR-195/16 family improved the effect of radiotherapy via blocking the programmed death-1 ligand 1 (PD-L1) immune checkpoint along with activation of T cells in the tumor microenvironment (Tao et al. 2018). Therefore, specific miRNAs determine the tumor response to radiation via multiple mechanisms. Accordingly, manipulation of their expression either by mimicking or inhibiting has attracted great interest for miRNAbased interventions to improve radiotherapy effectiveness (Gandellini et al. 2014). Thus, it is possible to use miRNAs as a potential adjuvant for radiotherapy.

\section{miRNAs involved in radiotherapy-related toxicity}

Apart from tumor sensitivity to radiation, miRNAs are closely related to the side effects induced by radiotherapy. They act as mediators to affect bystander effects through exosomes, which increases the risk of normal cellular injury and the likelihood of secondary cancer after radiotherapy (Yahyapour et al. 2018). Radiation-induced miR-21 could be transferred to recipient or bystander cells through exosomes, which resulted in bystander-like micronucleus formation, oxidative stressand DNA damage (Tian et al. 2015; Xu et al. 2015; Yin et al. 2015). However, unlike miR-21, miR-495acted as protector against radiation-induced bystander effects. Its overexpression produced fewer necrotic foci in adjacent, non-irradiated tissue after tumors received local irradiation compared with the low expression group (Fu et al. 2016). Lung fibrosis is the most serious side effect of lung cancer radiotherapy on normal tissue. IR-induced miR-21 was sufficient to promote the radiation-induced pulmonary fibrotic response, concurrent with EMT and collagen deposition, while miR-29 had a converse function to repress type I collagen against radiationinduced fibrosis (Kwon et al. 2016; Yano et al. 2017). miR$1,-21,-208,-133,-29,-199 b,-221,-222$, and -155 were dysregulated in radiation-induced heart diseases (Kura et al. 2017). miR-200c was reported to radiation-induced oral mucositis, which almost happened in the patients receiving radiotherapy for head and neck cancer. Inhibition of miR200c suppressed expression of pro-inflammatory cytokines transforming growth factor- $\beta$ (TGF- $\beta$ ), tumor necrosis factor- $\alpha$ (TNF- $\alpha$ ) and interleukin- $1 \alpha$ (IL- $1 \alpha)$, and increased the production of molecules associated with EMT (snail homologue 1(Snail), vimentin, ZEB1, and polycomb complex protein BMI-1 (Bmi-1)) (Tao et al. 2019). Furthermore, abdominal and pelvic radiotherapies have been reported to impair distant cognitive functions, whereas inhibition of miR$34 a-5 p$ and restoring expression of its target gene, brainderived neurotrophic factor (Bndf), relieved this condition effectively (Cui et al. 2017).

\section{miRNAs may serve as novel biomarkers for accidental and professional exposure to IR}

Over three decades, a growing body of evidence has shown that miRNAs have the potential to be useful diagnostic and prognostic biomarkers in clinic. miRNAs are stable and 
Table 1 The miRNAs and the relationship between miRNAs and radiosensitivity in multiple cancers

\begin{tabular}{|c|c|c|c|}
\hline Cancers & miRs & $\begin{array}{l}\text { Response } \\
\text { to IR }\end{array}$ & Refs \\
\hline \multirow[t]{3}{*}{ Breast cancer } & $\operatorname{miR}-144$ & Resistance & Yu et al. (2015a) \\
\hline & miR-200c & Sensitivity & Sun et al. (2015) \\
\hline & Let-7d & Sensitivity & Sun et al. (2016) \\
\hline \multirow[t]{5}{*}{ Prostate cancer } & $\operatorname{miR}-145$ & Sensitivity & Gong et al. (2015); Xue et al. (2015) \\
\hline & $\operatorname{miR}-205$ & Sensitivity & Wang et al. (2016b); Xu et al. (2016) \\
\hline & miR-30a & Sensitivity & Xu et al. (2016) \\
\hline & miR-144 & Sensitivity & Gu et al. (2016) \\
\hline & $\operatorname{miR}-124$ & Sensitivity & Gu et al. (2016) \\
\hline \multirow[t]{9}{*}{ Lung cancer } & $\operatorname{miR}-21$ & Resistance & $\begin{array}{l}\text { Jiang et al. (2017); Liu et al. (2014); Song et al. (2017); } \\
\text { Zhang et al. (2015a) }\end{array}$ \\
\hline & $\operatorname{miR}-155$ & Resistance & Lv et al. (2016) \\
\hline & $\operatorname{miR}-34 a$ & Sensitivity & Cortez et al. (2015); He et al. (2017b) \\
\hline & $\operatorname{miR}-9$ & Sensitivity & Wei et al. (2019) \\
\hline & $\operatorname{miR}-18 \mathrm{a}$ & Sensitivity & Shen et al. (2015) \\
\hline & miR-124 & Sensitivity & Hao et al. (2017) \\
\hline & miR-200c & Sensitivity & Zhai et al. (2016) \\
\hline & miR-339-5p & Sensitivity & Wang et al. (2018) \\
\hline & miR-30a & Sensitivity & Guo et al. (2017) \\
\hline \multirow{5}{*}{$\begin{array}{l}\text { Nasopharyngeal } \\
\text { cancer }\end{array}$} & miR-21 & Resistance & Zhu et al. (2015) \\
\hline & miR-203 & Sensitivity & Qu et al. (2015) \\
\hline & $\operatorname{miR}-222$ & Resistance & Wu et al. (2018b) \\
\hline & $\operatorname{miR}-9$ & Resistance & Zheng et al. (2015a) \\
\hline & miR-124 & Sensitivity & Zhang et al. (2017) \\
\hline \multirow[t]{4}{*}{ Colorectal cancer } & miR-155 & Resistance & Khoshinani et al. (2017) \\
\hline & miR-222 & Resistance & Khoshinani et al. (2017) \\
\hline & miR-185 & Sensitivity & Afshar et al. (2018) \\
\hline & Let-7e & Sensitivity & Samadi et al. (2019) \\
\hline \multirow[t]{4}{*}{ Cervical cancer } & miR-145 & Sensitivity & Ye et al. (2015) \\
\hline & miR-18a & Sensitivity & Liu et al. (2015) \\
\hline & miR-125a & Sensitivity & Pedroza-Torres et al. (2018) \\
\hline & $\operatorname{miR}-375$ & Sensitivity & Song et al. (2015) \\
\hline \multirow{5}{*}{$\begin{array}{l}\text { Esophageal } \\
\text { cancer }\end{array}$} & miR-21 & Resistance & Li et al. (2018a) \\
\hline & miR-205 & Resistance & Pan et al. (2017) \\
\hline & $\operatorname{miR}-124$ & Sensitivity & Zhang et al. (2016) \\
\hline & miR-200c & Sensitivity & Zheng et al. (2017) \\
\hline & miR-339-5p & Resistance & Luo et al. (2019) \\
\hline \multirow[t]{2}{*}{ Liver cancer } & $\operatorname{miR}-34 a$ & Sensitivity & Li et al. (2016) \\
\hline & miR-203 & Sensitivity & Shao et al. (2018) \\
\hline
\end{tabular}

steadily exist in multiple biofluids such as plasma, serum, blood, and urine, and even in tissues fixed in formalin (Duan et al. 2020; Enelund et al. 2017; Ma et al. 2016a). These advantages meet the criteria of becoming a biomarker that is stable post-IR exposure and allows repeated testing in a minimally invasive manner. Most miRNAs are specific to tissues and evolutionarily conserved across species (Huang 2017; Vishnoi and Rani 2017). In the case of human acute radiation syndrome caused by accidental or deliberate exposure to radiation, it is of particular importance for exposed person to be rapidly and accurately classified into definable susceptible population. Małachowska et al. 
(2020) conducted experiments in nonhuman primates that share $>95 \%$ genetic information with humans. They revealed that the combination of serum concentrations of miR-133b/215/375 was able to classify irradiated versus unirradiated animals and two miRNAs (miR-30a and miR126) were identified as predictors of radiation-induced fatality in nonhuman primates. Another study suggested that serum miRNAs could serve as functional dosimeters for early indication after hematopoietic injury caused by radiation (Acharya et al. 2015). In this study, miR-130a-3p was upregulated, whereas miR-150-5p, -142-5p, -706, and -342$3 p$ expressions were significantly decreased after exposure to total body irradiation dose of $2 \mathrm{~Gy}$. Furthermore, differential expression of five miRNAs (miR-136-5p, -17-3p, -126-3p, $322-3 p$, and $-34 b-3 p$ ) effectively distinguished the high sublethal group (6.5 Gy) from the low-dose sublethal group (2 Gy), and differential expression of miR-30a-3p/30c-5p distinguished lethal ( $8 \mathrm{~Gy}$ ) and sublethal (6.5 Gy) groups. In addition to biomarkers to assess radiation injury, miRNAs may be applied as clinical biomarkers in the prediction and prognosis of radiotherapy effects (details in Table 2). Some miRNAs indicate sensitivity or resistance to IR in patients with various kinds of cancers, who received radiotherapy previously (details in Table 2) (Hoey et al. 2018; Wang et al. 2019; Wei et al. 2017). These miRNAs probably could be used as biomarkers for radiosensitivity or radioresistance. Furthermore, miRNAs have a close relationship with the prognosis of post-radiotherapy (details in Table 2) (Bell et al. 2015; Hoey et al. 2018; Ma et al. 2016b). In esophageal squamous cell carcinomas, miR-16 showed significantly higher expression in patients with good outcomes post-radiotherapy ( $\mathrm{Yu}$ et al. 2015b). Head and neck carcinoma patients with high expression of miR-15b-5p showed less locoregional release and longer survival compared with patients who showed low expression (Ahmad et al. 2019). In the late effect of radiotherapy, miR-125a was closely related to induction of pneumonitis in lung cancer patients who received radiotherapy (Quan et al. 2018), and low Ku80 expression and high miR-99a expression were promising predictors of rectal bleeding after radiotherapy for prostate cancer (Someya et al. 2015). In radiation-induced renal tubular injury, urinary hsa-miR-1224 was considered as a potential early responder to nephropathy,
Table 2 miRNAs related to clinical outcome of radiotherapy in different cancer patients

\begin{tabular}{|c|c|c|c|}
\hline Cancers & miRs & $\begin{array}{l}\text { Clinical outcome of radiotherapy in } \\
\text { patients }\end{array}$ & Refs \\
\hline \multirow[t]{3}{*}{$\begin{array}{l}\text { Non-small cell } \\
\text { lung cancer }\end{array}$} & $\mathrm{miR}-208 \mathrm{a} / 21-5 \mathrm{p}$ & $\begin{array}{l}\text { Highly expressed in radioresistant } \\
\text { patients. }\end{array}$ & $\begin{array}{l}\text { Song et al. (2017); Tang } \\
\text { et al. (2016) }\end{array}$ \\
\hline & $\operatorname{miR}-125 \mathrm{a}$ & $\begin{array}{l}\text { Associated with induction of } \\
\text { radiation-induced pneumonitis. }\end{array}$ & Quan et al. (2018) \\
\hline & miR-95 & $\begin{array}{l}\text { Closely related to recurrent after } \\
\text { radiotherapy. }\end{array}$ & Ma et al. (2016b) \\
\hline \multirow[t]{3}{*}{ Prostate cancer } & $\operatorname{miR}-4516 / 601$ & $\begin{array}{l}\text { Associated with biochemical failure of } \\
\text { post-salvage radiotherapy. }\end{array}$ & Bell et al. (2015) \\
\hline & miR-99a & $\begin{array}{l}\text { Associated with rectal bleeding after } \\
\text { radiotherapy. }\end{array}$ & Someya et al. (2015) \\
\hline & miR-106a & $\begin{array}{l}\text { Overexpressed in radioresistant cancer } \\
\text { cell and related to biochemical } \\
\text { recurrence within five years after } \\
\text { prostatectomy. }\end{array}$ & Hoey et al. (2018) \\
\hline \multirow[t]{2}{*}{$\begin{array}{l}\text { Esophageal } \\
\text { cancer }\end{array}$} & $\mathrm{miR}-133 \mathrm{a} / 27 \mathrm{a}$ & $\begin{array}{l}\text { Highly expressed in radiosensitive } \\
\text { patients. }\end{array}$ & $\begin{array}{l}\text { Wang et al. (2019); } \\
\text { Yang et al. (2017) }\end{array}$ \\
\hline & miR-16 & $\begin{array}{l}\text { Highly expressed in patients with good } \\
\text { outcome at post-radiotherapy }\end{array}$ & Yu et al. (2015b) \\
\hline $\begin{array}{l}\text { Head and neck } \\
\text { carcinoma }\end{array}$ & $\operatorname{miR}-15 b-5 p$ & $\begin{array}{l}\text { Associated with less locoregional } \\
\text { release and longer survival after } \\
\text { intensity-modulated radiotherapy }\end{array}$ & Ahmad et al. (2019) \\
\hline \multirow[t]{2}{*}{ Leukemia } & miR-1224 & $\begin{array}{l}\text { Early responder in radiation-induced re- } \\
\text { nal tubular injury }\end{array}$ & Bhayana et al. (2017) \\
\hline & miR-21 & $\begin{array}{l}\text { Late responder in radiation-induced re- } \\
\text { nal tubular injury }\end{array}$ & Bhayana et al. (2017) \\
\hline $\begin{array}{l}\text { Nasopharyngeal } \\
\text { carcinoma }\end{array}$ & $\operatorname{miR}-24$ & $\begin{array}{l}\text { Associated with recurrent and sensitize } \\
\text { cancer to IR }\end{array}$ & Wang et al. (2016a) \\
\hline Cervical cancer & miR-18a/125a/145 & $\begin{array}{l}\text { Highly expressed in radiosensitive } \\
\text { patients }\end{array}$ & $\begin{array}{l}\text { Liu et al. (2015); } \\
\text { Pedroza-Torres et al. } \\
\text { (2018); Wei et al. } \\
\text { (2017) }\end{array}$ \\
\hline
\end{tabular}


while urinary hsa-miR-21 was a late responder (Bhayana et al. 2017). Taken together, miRNAs as biomarkers may facilitate precise dose escalation and prediction of prognosis during radiotherapy. These studies support that miRNAs have strong prospects in the clinic, although the results of current studies are too heterogeneous and preliminary.

\section{Perspectives}

Overall, the current research has shown that miRNAs are able to affect the mechanisms and pathways involving to cellular responses to IR, although the studies are somewhat divergent and the heterogeneous results require further systematic analysis for normalization. Currently, miR-34a that has been clearly identified as a tumor suppressor has reached the clinical trial stage, and various nanoparticles as miRNA carriers have emerged (Beg et al. 2017; Bejerano et al. 2018; Campani et al. 2016; Ren et al. 2019). These studies show that miRNA therapeutics have a good perspective in radiation oncology (Rancoule et al. 2016; Rupaimoole and Slack 2017). Moreover, with progressively deepening of our understanding of the regulatory mechanisms of miRNAs during exposure to ionizing radiation, miRNAs may be accepted as biomarkers at the levels of proteins in the near future, which will be not only used to rapidly classify injury from radiation exposure, but also treatment responses, untoward reactions, and customized radiotherapies.

Acknowledgments The reviews and editors are appreciated for comments and suggestions to improve the paper.

Authors' contributions $\mathrm{YC}$ and JC contributed equally to this work and were major contributors in draft manuscripts and illustration of the figures. YG, WS, and YW were involved in literature search. LY was involved in conception and instruction of the study and critically revised this manuscript.

Funding This work was supported by Hunan Natural Science Foundation (No. 2019JJ40238), Key Scientific Research Project of Hunan Health Commission (No.202102051816), COVID-19 Emergence Project of University of South China for Scientific Research on Epidemic Prevention and Control (No.35), the Defense Industrial Technology Development Program (No. JCKY2016403C001), National Natural Science Foundation of China (No. 81400117), China Postdoctoral Science Foundation (No. 2014 M562115), and the Research Initiation Funding of University of South China for the Returned Scholars From Abroad (No. 2014XQD46) and University Students Study and Innovation Pilot Project (No.X2019132).

Data availability The data and materials in this article are online and publicly available without request.

\section{Compliance with ethical standards}

Conflict of interest The authors declare that they have no conflict of interest.

\section{References}

Acharya SS, Fendler W, Watson J, Hamilton A, Pan Y, Gaudiano E, Moskwa P, Bhanja P, Saha S, Guha C, Parmar K, Chowdhury D (2015) Serum microRNAs are early indicators of survival after radiation-induced hematopoietic injury. Science translational medicine 7:287-269

Afshar S, Najafi R, Sedighi Pashaki A, Sharifi M, Nikzad S, Gholami MH, Khoshghadam A, Amini R, Karimi J, Saidijam M (2018) MiR185 enhances radiosensitivity of colorectal cancer cells by targeting IGF1R and IGF2. Biomed Pharmacother 106:763-769

Ahmad P, Sana J, Slavik M, Gurin D, Radova L, Gablo NA, Kazda T, Smilek P, Horakova Z, Gal B, Hermanova M, Slampa P, Slaby O (2019) MicroRNA-15b-5p predicts locoregional relapse in head and neck carcinoma patients treated with intensity-modulated radiotherapy. Cancer Genomics Proteomics 16:139-146

Aryankalayil MJ, Chopra S, Makinde A, Eke I, Levin J, Shankavaram U, MacMillan L, Vanpouille-Box C, Demaria S, Coleman CN (2018) Microarray analysis of miRNA expression profiles following whole body irradiation in a mouse model. Biomarkers : biochemical indicators of exposure, response, and susceptibility to chemicals 23: 689-703

Atkins KM, Rawal B, Chaunzwa TL, Lamba N, Bitterman DS, Williams CL, Kozono DE, Baldini EH, Chen AB, Nguyen PL, D'Amico AV, Nohria A, Hoffmann U, Aerts H, Mak RH (2019) Cardiac radiation dose, cardiac disease, and mortality in patients with lung cancer. Journal of the American College of Cardiology 73:2976-2987

Awasthi P, Foiani M, Kumar A (2016) ATM and ATR signaling at a glance. Journal of cell science 129:1285

Bartel DP (2004) MicroRNAs: genomics, biogenesis, mechanism, and function. Cell 116:281-297

Beg MS, Brenner AJ, Sachdev J, Borad M, Kang YK, Stoudemire J, Smith S, Bader AG, Kim S, Hong DS (2017) Phase I study of MRX34, a liposomal miR-34a mimic, administered twice weekly in patients with advanced solid tumors. Investigational new drugs 35:180-188

Bejerano T, Etzion S, Elyagon S, Etzion Y, Cohen S (2018) Nanoparticle delivery of miRNA-21 mimic to cardiac macrophages improves myocardial remodeling after myocardial infarction. Nano letters 18:5885-5891

Bell EH, Kirste S, Fleming JL, Stegmaier P, Drendel V, Mo X, Ling S, Fabian D, Manring I, Jilg CA, Schultze-Seemann W, McNulty M, Zynger DL, Martin D, White J, Werner M, Grosu AL, Chakravarti A (2015) A novel miRNA-based predictive model for biochemical failure following post-prostatectomy salvage radiation therapy. PLoS One 10:e0118745

Bhayana S, Song F, Jacob J, Fadda P, Denko NC, Xu-Welliver M, Chakravarti A, Jacob NK (2017) Urinary miRNAs as biomarkers for noninvasive evaluation of radiation-induced renal tubular injury. Radiat Res 188:626-635

Birts CN, Banerjee A, Darley M, Dunlop CR, Nelson S, Nijjar SK, Parker R, West J, Tavassoli A, Rose-Zerilli MJJ, Blaydes JP (2020) p53 is regulated by aerobic glycolysis in cancer cells by the CtBP family of NADH-dependent transcriptional regulators. Science signaling 13

Boutros R, Lobjois V, Ducommun B (2007) CDC25 phosphatases in cancer cells: key players? Good targets? Nature reviews. Cancer 7: 495-507

Bueno MJ, Perez de Castro I, Gomez de Cedron M, Santos J, Calin GA, Cigudosa JC, Croce CM, Fernandez-Piqueras J, Malumbres M (2008) Genetic and epigenetic silencing of microRNA-203 enhances ABL1 and BCR-ABL1 oncogene expression. Cancer Cell 13:496-506

Cai S, Shi GS, Cheng HY, Zeng YN, Li G, Zhang M, Song M, Zhou PK, Tian Y, Cui FM, Chen Q (2017) Exosomal miR-7 mediates 
bystander autophagy in lung after focal brain irradiation in mice. Int J Biol Sci 13:1287-1296

Campani V, De Rosa G, Misso G, Zarone MR, Grimaldi A (2016) Lipid nanoparticles to deliver miRNA in cancer. Current pharmaceutical biotechnology 17:741-749

Carter RJ, Nickson CM, Thompson JM, Kacperek A, Hill MA, Parsons JL (2019) Characterisation of deubiquitylating enzymes in the cellular response to high-LET ionizing radiation and complex DNA damage. Int J Radiat Oncol Biol Phys 104:656-665

Chen C, Lu J, Hao L, Zheng Z, Zhang N, Wang Z (2016) Discovery and characterization of miRNAs in mouse thymus responses to ionizing radiation by deep sequencing. Int J Radiat Biol 92:548-557

Chen X, Wu L, Li D, Xu Y, Zhang L, Niu K, Kong R, Gu J, Xu Z, Chen Z, Sun J (2018) Radiosensitizing effects of miR-18a-5p on lung cancer stem-like cells via downregulating both ATM and HIF-1 $\alpha$. Cancer Med 7:3834-3847

Chiba M, Monzen S, Iwaya C, Kashiwagi Y, Yamada S, Hosokawa Y, Mariya Y, Nakamura T, Wojcik A (2018) Serum miR-375-3p increase in mice exposed to a high dose of ionizing radiation. Scientific Reports 8

Cortez MA, Valdecanas D, Niknam S, Peltier HJ, Diao L, Giri U, Komaki R, Calin GA, Gomez DR, Chang JY, Heymach JV, Bader AG, Welsh JW (2015) In vivo delivery of miR-34a sensitizes lung tumors to radiation through RAD51 regulation. Mol Ther Nucleic Acids 4:e270

Cui J, Cheng Y, Zhang P, Sun M, Gao F, Liu C, Cai J (2014) Down regulation of miR200c promotes radiation-induced thymic lymphoma by targeting BMI1. J Cell Biochem 115:1033-1042

Cui M, Xiao H, Li Y, Dong J, Luo D, Li H, Feng G, Wang H, Fan S (2017) Total abdominal irradiation exposure impairs cognitive function involving miR-34a-5p/BDNF axis. Biochim Biophys Acta Mol Basis Dis 1863:2333-2341

Dinh T-KT, Fendler W, Chałubińska-Fendler J, Acharya SS, O'Leary C, Deraska PV, D'Andrea AD, Chowdhury D, Kozono D (2016) Circulating miR-29a and miR-150 correlate with delivered dose during thoracic radiation therapy for non-small cell lung cancer. Radiation Oncology 11

Dogu Y, Díaz J (2009) Mathematical model of a network of interaction between p53 and Bcl-2 during genotoxic-induced apoptosis. Biophysical chemistry 143:44-54

Douple EB, Mabuchi K, Cullings HM, Preston DL, Kodama K, Shimizu Y, Fujiwara S, Shore RE (2011) Long-term radiation-related health effects in a unique human population: lessons learned from the atomic bomb survivors of Hiroshima and Nagasaki. Disaster medicine and public health preparedness 5(Suppl 1):S122-S133

Duan XM, Liu XN, Li YX, Cao YQ, Silayiding A, Zhang RK, Wang JP (2019) MicroRNA-498 promotes proliferation, migration, and invasion of prostate cancer cells and decreases radiation sensitivity by targeting PTEN. The Kaohsiung Journal of Medical Sciences 35: 659-671

Duan Y, Zhang Y, Peng W, Jiang P, Deng Z, Wu C (2020) MiR-7-5pand miR-451 as diagnostic biomarkers for papillary thyroid carcinoma in formalin-fixed paraffin-embedded tissues. Die Pharmazie 75: 266-270

El Bezawy R, Cominetti D, Fenderico N, Zuco V, Beretta GL, Dugo M, Arrighetti N, Stucchi C, Rancati T, Valdagni R, Zaffaroni N, Gandellini P (2017) miR-875-5p counteracts epithelial-tomesenchymal transition and enhances radiation response in prostate cancer through repression of the EGFR-ZEB1 axis. Cancer Letters 395:53-62

Enelund L, Nielsen LN, Cirera S (2017) Evaluation of microRNA stability in plasma and serum from healthy dogs. MicroRNA (Shariqah, United Arab Emirates) 6:42-52

Fu J, Jiang M, Zhang M, Zhang J, Wang Y, Xiang S, Xu X, Ye Q, Song H (2016) MiR-495 functions as an adjuvant to radiation therapy by reducing the radiation-induced bystander effect. Acta Biochim Biophys Sin (Shanghai) 48:1026-1033

Galaktionov K, Chen X, Beach D (1996) Cdc25 cell-cycle phosphatase as a target of c-myc. Nature 382:511-517

Gandellini P, Rancati T, Valdagni R, Zaffaroni N (2014) miRNAs in tumor radiation response: bystanders or participants? Trends in molecular medicine 20:529-539

Gao F, Chen S, Sun M, Mitchel RE, Li B, Chu Z, Cai J, Liu C (2015) MiR-467a is upregulated in radiation-induced mouse thymic lymphomas and regulates apoptosis by targeting Fas and Bax. Int J Biol Sci 11:109-121

Gong P, Zhang T, He D, Hsieh J-T (2015) MicroRNA-145 Modulates tumor sensitivity to radiation in prostate cancer. Radiation Research 184:630-638

Grabenbauer GG, Holger G (2016) Management of radiation and chemotherapy related acute toxicity in gastrointestinal cancer. Best Pract Res Clin Gastroenterol 30:655-664

Gu H, Liu M, Ding C, Wang X, Wang R, Wu X, Fan R (2016) Hypoxiaresponsive miR-124 and miR-144 reduce hypoxia-induced autophagy and enhance radiosensitivity of prostate cancer cells via suppressing PIM1. Cancer Medicine 5:1174-1182

Guo Y, Sun W, Gong T, Chai Y, Wang J, Hui B, Li Y, Song L, Gao Y (2017) miR-30a radiosensitizes non-small cell lung cancer by targeting ATF1 that is involved in the phosphorylation of ATM. Oncol Rep 37:1980-1988

Halimi M, Shahabi A, Moslemi D, Parsian H, Asghari SM, Sariri R, Yeganeh F, Zabihi E (2016) Human serum miR-34a as an indicator of exposure to ionizing radiation. Radiation and Environmental Biophysics 55:423-429

Hamada N, Sato T (2016) Cataractogenesis following high-LET radiation exposure. Mutat Res 770:262-291

Hao C, Xu X, Ma J, Xia J, Dai B, Liu L, Ma Y (2017) MicroRNA-124 regulates the radiosensitivity of non-small cell lung cancer cells by targeting TXNRD1. Oncol Lett 13:2071-2078

He J, Tian N, Yang Y, Jin L, Feng X, Hua J, Lin S, Wang B, Li H, Wang J (2017a) miR-185 enhances the inhibition of proliferation and migration induced by ionizing radiation in melanoma. Oncology Letters 13:2442-2448

He X, Yang A, McDonald DG, Riemer EC, Vanek KN, Schulte BA, Wang GY (2017b) MiR-34a modulates ionizing radiation-induced senescence in lung cancer cells. Oncotarget 8:69797-69807

He Y, Zhang Y, Li H, Zhang H, Li Z, Xiao L, Hu J, Ma Y, Zhang Q, Zhao X (2018) Comparative profiling of MicroRNAs reveals the underlying toxicological mechanism in mice testis following carbon ion radiation. dose-response : a publication of International Hormesis Society $16: 1559325818778633$

Hoey C, Ray J, Jeon J, Huang X, Taeb S, Ylanko J, Andrews DW, Boutros PC, Liu SK (2018) miRNA-106a and prostate cancer radioresistance: a novel role for LITAF in ATM regulation. Mol Oncol 12:1324-1341

Hou W, Song L, Zhao Y, Liu Q, Zhang S (2017) Inhibition of Beclin-1mediated autophagy by MicroRNA-17-5p enhanced the radiosensitivity of glioma cells. Oncol Res 25:43-53

Huang W (2017) MicroRNAs: biomarkers, diagnostics, and therapeutics. Methods in molecular biology (Clifton, N.J.) 1617:57-67

Iizuka D, Imaoka T, Nishimura M, Kawai H, Suzuki F, Shimada Y (2012) Aberrant microRNA expression in radiation-induced rat mammary cancer: the potential role of miR-194 overexpression in cancer cell proliferation. Radiation Research 179

Jiang LP, He CY, Zhu ZT (2017) Role of microRNA-21 in radiosensitivity in non-small cell lung cancer cells by targeting PDCD4 gene. Oncotarget 8:23675-23689

Jin MH, Oh DY (2019) ATM in DNA repair in cancer. Pharmacology \& therapeutics 203:107391

Khoshinani HM, Afshar S, Pashaki AS, Mahdavinezhad A, Nikzad S, Najafi R, Amini R, Gholami MH, Khoshghadam A, Saidijam M 
(2017) Involvement of miR-155/FOXO3a and miR-222/PTEN in acquired radioresistance of colorectal cancer cell line. Japanese Journal of Radiology 35:664-672

Kim ES, Choi YE, Hwang SJ, Han YH, Park MJ, Bae IH (2016) IL-4, a direct target of miR-340/429, is involved in radiation-induced aggressive tumor behavior in human carcinoma cells. Oncotarget 7: 86836-86856

Kim EM, Jung CH, Kim J, Hwang SG, Park JK, Um HD (2017) The p53/ p21 complex regulates cancer cell invasion and apoptosis by targeting Bcl-2 family proteins. Cancer Res 77:3092-3100

Korpela E, Vesprini D, Liu SK (2015) MicroRNA in radiotherapy: miRage or miRador? British journal of cancer 112:777-782

Krieger KL, Hu WF, Ripperger T, Woods NT (2019) Functional impacts of the BRCA1-mTORC2 interaction in breast cancer. Int J Mol Sci 20

Kura B, Babal P, Slezak J (2017) Implication of microRNAs in the development and potential treatment of radiation-induced heart disease. Canadian journal of physiology and pharmacology 95:12361244

Kwak SY, Kim BY, Ahn HJ, Yoo JO, Kim J, Bae IH, Han YH (2015) Ionizing radiation-inducible miR-30e promotes glioma cell invasion through EGFR stabilization by directly targeting CBL-B. FEBS J 282:1512-1525

Kwon OS, Kim KT, Lee E, Kim M, Choi SH, Li H, Fornace AJ Jr, Cho JH, Lee YS, Lee JS, Lee YJ, Cha HJ (2016) Induction of MiR-21 by stereotactic body radiotherapy contributes to the pulmonary fibrotic response. PLoS One 11:e0154942

Lee JH, Liu R, Li J, Wang Y, Tan L, Li XJ, Qian X, Zhang C, Xia Y, Xu D, Guo W, Ding Z, Du L, Zheng Y, Chen Q, Lorenzi PL, Mills GB, Jiang T, Lu Z (2018) EGFR-Phosphorylated platelet isoform of phosphofructokinase 1 promotes PI3K activation. Molecular cell 70:197-210.e7

Li X, Lu P, Li B, Yang R, Chu Y, Zhang Z, Wan H, Niu C, Wang C, Luo K (2016) Sensitization of hepatocellular carcinoma cells to irradiation by miR-34a through targeting lactate dehydrogenase-A. Mol Med Rep 13:3661-3667

Li F, Lv JH, Liang L, Wang JC, Li CR, Sun L, Li T (2018a) Downregulation of microRNA-21 inhibited radiation-resistance of esophageal squamous cell carcinoma. Cancer Cell Int 18:39

Li H, Jin X, Chen B, Li P, Li Q (2018b) Autophagy-regulating microRNAs: potential targets for improving radiotherapy. J Cancer Res Clin Oncol 144:1623-1634

Li L, Liu H, Du L, Xi P, Wang Q, Li Y, Liu D (2018c) miR-449a suppresses LDHA-mediated glycolysis to enhance the sensitivity of non-small cell lung cancer cells to ionizing radiation. Oncology Research Featuring Preclinical and Clinical Cancer Therapeutics 26: 547-556

Liu C, Li B, Cheng Y, Lin J, Hao J, Zhang S, Mitchel RE, Sun D, Ni J, Zhao L, Gao F, Cai J (2011) MiR-21 plays an important role in radiation induced carcinogenesis in $\mathrm{BALB} / \mathrm{c}$ mice by directly targeting the tumor suppressor gene Big-h3. Int J Biol Sci 7:347363

Liu J, Zhu H, Yang X, Ge Y, Zhang C, Qin Q, Lu J, Zhan L, Cheng H, Sun X (2014) MicroRNA-21 is a novel promising target in cancer radiation therapy. Tumour Biol 35:3975-3979

Liu SHA, Pan X, Yang QIN, Wen LU, Jiang YAO, Zhao Y, Li G (2015) MicroRNA-18a enhances the radiosensitivity of cervical cancer cells by promoting radiation-induced apoptosis. Oncology Reports 33:2853-2862

Lu J, Chen C, Hao L, Zheng Z, Zhang N, Wang Z (2016) MiRNA expression profile of ionizing radiation-induced liver injury in mouse using deep sequencing. Cell Biology International 40:873886

Luo J, Chen J, He L (2015) mir-129-5p attenuates irradiation-induced autophagy and decreases radioresistance of breast cancer cells by targeting HMGB1. Medical Science Monitor 21:4122-4129
Luo A, Zhou X, Shi X, Zhao Y, Men Y, Chang X, Chen H, Ding F, Li Y, Su D, Xiao Z, Hui Z, Liu Z (2019) Exosome-derived miR-339-5p mediates radiosensitivity by targeting Cdc25A in locally advanced esophageal squamous cell carcinoma. Oncogene 38:4990-5006

Lv X, Yao L, Zhang J, Han P, Li C (2016) Inhibition of microRNA-155 sensitizes lung cancer cells to irradiation via suppression of HK2modulated glucose metabolism. Molecular Medicine Reports 14: $1332-1338$

Ma L, Zhang XQ, Zhou DX, Cui Y, Deng LL, Yang T, Shao Y, Ding M (2016a) Feasibility of urinary microRNA profiling detection in intrahepatic cholestasis of pregnancy and its potential as a noninvasive biomarker. Sci Rep 6:31535

Ma W, Ma CN, Li XD, Zhang YJ (2016b) Examining the effect of gene reduction in miR-95 and enhanced radiosensitivity in non-small cell lung cancer. Cancer Gene Ther 23:66-71

Maier P, Hartmann L, Wenz F, Herskind C (2016) Cellular pathways in response to ionizing radiation and their targetability for tumor radiosensitization. Int J Mol Sci 17

Małachowska B, Tomasik B, Stawiski K, Kulkarni S, Guha C, Chowdhury D, Fendler W (2020) Circulating microRNAs as biomarkers of radiation exposure: a systematic review and meta-analysis. International Journal of Radiation Oncology*Biology*Physics 106:390-402

Malla B, Aebersold DM, Dal Pra A (2018) Protocol for serum exosomal miRNAs analysis in prostate cancer patients treated with radiotherapy. Journal of Translational Medicine 16

Mao A, Zhao Q, Zhou X, Sun C, Si J, Zhou R, Gan L, Zhang H (2016) MicroRNA-449a enhances radiosensitivity by downregulation of cMyc in prostate cancer cells. Sci Rep 6:27346

Mei Z, Su T, Ye J, Yang C, Zhang S, Xie C (2015) The miR-15 family enhances the radiosensitivity of breast cancer cells by targeting G2 checkpoints. Radiation Research 183:196-207

Mettler FA Jr, Gus'kova AK, Gusev I (2007) Health effects in those with acute radiation sickness from the Chernobyl accident. Health physics 93:462-469

Mueck K, Rebholz S, Harati M, Rodemann H, Toulany M (2017) Akt1 stimulates homologous recombination repair of DNA double-strand breaks in a Rad51-Dependent Manner. International Journal of Molecular Sciences 18

Pajic M, Froio D, Daly S, Doculara L, Millar E, Graham PH, Drury A, Steinmann A, de Bock CE, Boulghourjian A, Zaratzian A, Carroll S, Toohey J, O'Toole SA, Harris AL, Buffa FM, Gee HE, Hollway GE, Molloy TJ (2018) miR-139-5p modulates radiotherapy resistance in breast cancer by repressing multiple gene networks of DNA repair and ROS defense. Cancer Res 78:501-515

Pan F, Mao H, Bu F, Tong X, Li J, Zhang S, Liu X, Wang L, Wu L, Chen R, Wei H, Li B, Li C, Yang Y, Steer CJ, Zhao J, Guo Y (2017) Sp1mediated transcriptional activation of miR-205 promotes radioresistance in esophageal squamous cell carcinoma. Oncotarget 8:5735-5752

Pedroza-Torres A, Campos-Parra AD, Millan-Catalan O, LoissellBaltazar YA, Zamudio-Meza H, Cantu de Leon D, MontalvoEsquivel G, Isla-Ortiz D, Herrera LA, Angeles-Zaragoza O, Robelo-Romero G, Herrera-Gomez A, Perez-Plasencia C (2018) MicroRNA-125 modulates radioresistance through targeting p21 in cervical cancer. Oncol Rep 39:1532-1540

Penha RCC, Pellecchia S, Pacelli R, Pinto LFR, Fusco A (2018) Ionizing radiation deregulates the MicroRNA expression profile in differentiated thyroid cells. Thyroid 28:407-421

Peters LJ, Withers HR, Thames HD Jr, Fletcher GH (1982) Tumor radioresistance in clinical radiotherapy. Int $\mathrm{J}$ Radiat Oncol Biol Phys 8:101-108

Piotto C, Biscontin A, Millino C, Mognato M (2018) Functional validation of miRNAs targeting genes of DNA double-strand break repair to radiosensitize non-small lung cancer cells. Biochimica et 
Biophysica Acta (BBA) - Gene Regulatory Mechanisms 1861: $1102-1118$

Port M, Herodin F, Valente M, Drouet M, Ullmann R, Doucha-Senf S, Lamkowski A, Majewski M, Abend M (2016) MicroRNA expression for early prediction of late occurring hematologic acute radiation syndrome in baboons. PLoS One 11:e0165307

Port M, Hérodin F, Valente M, Drouet M, Ostheim P, Majewski M, Abend M (2018) Persistent mRNA and miRNA expression changes in irradiated baboons. Scientific Reports 8

Qu JQ, Yi HM, Ye X, Zhu JF, Yi H, Li LN, Xiao T, Yuan L, Li JY, Wang YY, Feng J, He QY, Lu SS, Xiao ZQ (2015) MiRNA-203 reduces nasopharyngeal carcinoma radioresistance by targeting IL8/AKT signaling. Molecular Cancer Therapeutics 14:2653-2664

Quan HY, Yuan T, Hao JF (2018) A microRNA-125a variant, which affects its mature processing, increases the risk of radiationinduced pneumonitis in patients with non-small-cell lung cancer. Mol Med Rep 18:4079-4086

Rancoule C, Magné N, Vallard A, Guy JB, Rodriguez-Lafrasse C, Deutsch E, Chargari C (2016) Nanoparticles in radiation oncology: from bench-side to bedside. Cancer Lett 375:256-262

Ren L, Liu J, Zhang J, Wang J, Wei J, Li Y, Guo C, Sun Z, Zhou X (2019) Silica nanoparticles induce spermatocyte cell autophagy through microRNA-494 targeting AKT in GC-2spd cells. Environmental pollution (Barking, Essex : 1987) 255:113172

Rupaimoole R, Slack FJ (2017) MicroRNA therapeutics: towards a new era for the management of cancer and other diseases. Nat Rev Drug Discov 16:203-222

Samadi P, Afshar S, Amini R, Najafi R, Mahdavinezhad A, Sedighi Pashaki A, Gholami MH, Saidijam M (2019) Let-7e enhances the radiosensitivity of colorectal cancer cells by directly targeting insulin-like growth factor 1 receptor. J Cell Physiol 234(7):1071810725

Sato H, Ebi J, Tamaki T, Yukawa A, Nakajima M, Ohtake T, Suzuki Y (2018) Incidence of organizing pneumonia after whole-breast radiotherapy for breast cancer, and risk factor analysis. J Radiat Res 59: 298-302

Schaue D, McBride WH (2015) Opportunities and challenges of radiotherapy for treating cancer. Nat Rev Clin Oncol 12:527-540

Shao Y, Zhang D, Li X, Yang J, Chen L, Ning Z, Xu Y, Deng G, Tao M, Zhu Y, Jiang J (2018) MicroRNA-203 increases cell radiosensitivity via directly targeting Bmi-1 in hepatocellular carcinoma. Mol Pharm 15:3205-3215

Shen Z, Wu X, Wang Z, Li B, Zhu X (2015) Effect of miR-18a overexpression on the radiosensitivity of non-small cell lung cancer. International journal of clinical and experimental pathology 8:643648

Shimizu N, Ooka M, Takagi T, Takeda S, Hirota K (2015) Distinct DNA damage spectra induced by ionizing radiation in normoxic and hypoxic cells. Radiat Res 184:442-448

Smith TA, Kirkpatrick DR, Smith S, Smith TK, Pearson T, Kailasam A, Herrmann KZ, Schubert J, Agrawal DK (2017) Radioprotective agents to prevent cellular damage due to ionizing radiation. Journal of Translational Medicine 15:232

Someya M, Yamamoto H, Nojima M, Hori M, Tateoka K, Nakata K, Takagi M, Saito M, Hirokawa N, Tokino T, K-i S (2015) Relation between Ku80 and microRNA-99a expression and late rectal bleeding after radiotherapy for prostate cancer. Radiotherapy and Oncology 115:235-239

Song L, Liu S, Zeng S, Zhang L, Li X (2015) miR-375 modulates radiosensitivity of HR-HPV-positive cervical cancer cells by targeting UBE3A through the p53 pathway. Med Sci Monit 21:2210-2217

Song M, Wang Y, Shang ZF, Liu XD, Xie DF, Wang Q, Guan H, Zhou PK (2016) Bystander autophagy mediated by radiation-induced exosomal miR-7-5p in non-targeted human bronchial epithelial cells. BF. Sci Rep 6:30165
Song Y, Zuo Y, Qian XL, Chen ZP, Wang SK, Song L, Peng LP (2017) Inhibition of MicroRNA-21-5p promotes the radiation sensitivity of non-small cell lung cancer through HMSH2. Cell Physiol Biochem 43:1258-1272

Spycher BD, Lupatsch JE, Zwahlen M, Röösli M, Niggli F, Grotzer MA, Rischewski J, Egger M, Kuehni CE (2015) Background ionizing radiation and the risk of childhood cancer: a census-based nationwide cohort study. Environmental health perspectives 123:622-628

Sun Q, Liu T, Yuan Y, Guo Z, Xie G, Du S, Lin X, Xu Z, Liu M, Wang W, Yuan Q, Chen L (2015) MiR-200c inhibits autophagy and enhances radiosensitivity in breast cancer cells by targeting UBQLN1. Int J Cancer 136:1003-1012

Sun H, Ding C, Zhang H, Gao J (2016) Let-7 miRNAs sensitize breast cancer stem cells to radiation-induced repression through inhibition of the cyclin D1/Akt1/Wnt1 signaling pathway. Mol Med Rep 14: 3285-3292

Tang Y, Cui Y, Li Z, Jiao Z, Zhang Y, He Y, Chen G, Zhou Q, Wang W, Zhou X, Luo J, Zhang S (2016) Radiation-induced miR-208a increases the proliferation and radioresistance by targeting $\mathrm{p} 21$ in human lung cancer cells. J Exp Clin Cancer Res 35:7

Tang S, Liu B, Liu M, Li Z, Liu J, Wang H, Wang J, Oh YT, Shen L, Wang Y (2019) Ionizing radiation-induced growth in soft agar is associated with miR-21 upregulation in wild-type and DNA double strand break repair deficient cells. DNA Repair (Amst) 78:37-44

Tao Z, Xu S, Ruan H, Wang T, Song W, Qian L, Chen K (2018) MiR195/-16 family enhances radiotherapy via T cell activation in the tumor microenvironment by blocking the PD-L1 immune checkpoint. Cell Physiol Biochem 48:801-814

Tao J, Fan M, Zhou D, Hong Y, Zhang J, Liu H, Sharma S, Wang G (2019) Dong Q (2019) miR-200c modulates the pathogenesis of radiation-induced oral mucositis. Oxid Med Cell Longev 2352079

Tian W, Yin X, Wang L, Wang J, Zhu W, Cao J, Yang H (2015) The key role of miR-21-regulated SOD2 in the medium-mediated bystander responses in human fibroblasts induced by $\alpha$-irradiated keratinocytes. Mutat Res 780:77-85

Tian Y, Yan M, Zheng J, Li R, Lin J, Xu A, Liang Y, Zheng R, Yuan Y (2019) miR-483-5p decreases the radiosensitivity of nasopharyngeal carcinoma cells by targeting DAPK1. Lab Invest 99:602-611

Vahabi M, Pulito C, Sacconi A, Donzelli S, D'Andrea M, Manciocco V, Pellini R, Paci P, Sanguineti G, Strigari L, Spriano G, Muti P, Pandolfi PP, Strano S, Safarian S, Ganci F, Blandino G (2019) miR-96-5p targets PTEN expression affecting radiochemosensitivity of HNSCC cells. J Exp Clin Cancer Res 38:141

Vishnoi A, Rani S (2017) MiRNA biogenesis and regulation of diseases: an overview. Methods in molecular biology (Clifton, N.J.) 1509:110

Wang C, Qiao C (2017) MicroRNA-190b confers radio-sensitivity through negative regulation of $\mathrm{Bcl}-2$ in gastric cancer cells. Biotechnol Lett 39:485-490

Wang S, Pan Y, Zhang R, Xu T, Wu W, Zhang R, Wang C, Huang H, Calin CA, Yang H, Claret FX (2016a) Hsa-miR-24-3p increases nasopharyngeal carcinoma radiosensitivity by targeting both the 3'UTR and 5'UTR of Jab1/CSN5. Oncogene 35:6096-6108

Wang W, Liu J, Wu Q (2016b) MiR-205 suppresses autophagy and enhances radiosensitivity of prostate cancer cells by targeting TP53INP1. European review for medical and pharmacological sciences 20:92-100

Wang Y, Wang Y, Zhong W, Gulina K (2017) Correlation between miR19a inhibition and radiosensitivity in SiHa cervical cancer cells. Journal of B.U.ON. : official journal of the Balkan Union of Oncology 22:1505-1508

Wang J, Jiang M, Xia S (2018) miR-339-5p increases radiosensitivity of lung cancer cells by targeting phosphatases of regenerating liver-1 (PRL-1). Medical Science Monitor 24:8408-8416

Wang X, An D, Liu X, Wang X, Li B (2019) MicroRNA-27a downregulates the expression of Hsp90 and enhances the 
radiosensitivity in esophageal squamous cell carcinoma. Onco Targets Ther 12:5967-5977

Wei H, Wen-Ming C, Jun-Bo J (2017) Plasma miR-145 as a novel biomarker for the diagnosis and radiosensitivity prediction of human cervical cancer. J Int Med Res 45:1054-1060

Wei W, Dong Z, Gao H, Zhang YY, Shao LH, Jin LL, Lv YH, Zhao G, Shen YN, Jin SZ (2019) MicroRNA-9 enhanced radiosensitivity and its mechanism of DNA methylation in non-small cell lung cancer. Gene 710:178-185

Wu SJ, Chen J, Wu B, Wang YJ, Guo KY (2018a) MicroRNA-150 enhances radiosensitivity by inhibiting the AKT pathway in NK/T cell lymphoma. Journal of Experimental \& Clinical Cancer Research 37:18

Wu W, Chen X, Yu S, Wang R, Zhao R, Du C (2018b) microRNA-222 promotes tumor growth and confers radioresistance in nasopharyngeal carcinoma by targeting PTEN. Mol Med Rep 17:1305-1310

Xu S, Wang J, Ding N, Hu W, Zhang X, Wang B, Hua J, Wei W, Zhu Q (2015) Exosome-mediated microRNA transfer plays a role in radiation-induced bystander effect. RNA Biol 12:1355-1363

Xu CG, Yang MF, Fan JX, Wang W (2016) MiR-30a and miR-205 are downregulated in hypoxia and modulate radiosensitivity of prostate cancer cells by inhibiting autophagy via TP53INP1. European review for medical and pharmacological sciences 20:1501-1508

Xue G, Ren Z, Chen Y, Zhu J, Du Y, Pan D, Li X, Hu B (2015) A feedback regulation between miR-145 and DNA methyltransferase $3 \mathrm{~b}$ in prostate cancer cell and their responses to irradiation. Cancer Lett 361:121-127

Yahyapour R, Motevaseli E, Rezaeyan A, Abdollahi H, Farhood B, Cheki M, Najafi M, Villa V (2018) Mechanisms of radiation bystander and non-targeted effects: implications to radiation carcinogenesis and radiotherapy. Curr Radiopharm 11:34-45

Yan J, Qin Y, Yu J, Peng Q, Chen X (2018) MiR-340/iASPP axis affects UVB-mediated retinal pigment epithelium (RPE) cell damage. J Photochem Photobiol B 186:9-16

Yang Q-S, Jiang L-P, He C-Y, Tong Y-N, Liu Y-Y (2017) Up-regulation of MicroRNA-133a inhibits the MEK/ERK signaling pathway to promote cell apoptosis and enhance radio-sensitivity by targeting EGFR in esophageal cancer in vivo and in vitro. Journal of Cellular Biochemistry 118:2625-2634

Yang Z, Wa QD, Lu C, Pan W, Lu Z, Ao J (2018) miR-328-3p enhances the radiosensitivity of osteosarcoma and regulates apoptosis and cell viability via H2AX. Oncol Rep 39:545-553

Yano H, Hamanaka R, Nakamura-Ota M, Zhang JJ, Matsuo N, Yoshioka H (2017) Regulation of type I collagen expression by microRNA-29 following ionizing radiation. Radiation and Environmental Biophysics 57:41-54

Ye C, Sun NX, Ma Y, Zhao Q, Zhang Q, Xu C, Wang SB, Sun SH, Wang F, Li W (2015) MicroRNA-145 contributes to enhancing radiosensitivity of cervical cancer cells. FEBS Lett 589:702-709

Yin X, Tian W, Wang L, Wang J, Zhang S, Cao J, Yang H (2015) Radiation quality-dependence of bystander effect in unirradiated fibroblasts is associated with TGF- $\beta 1-\mathrm{Smad} 2$ pathway and miR21 in irradiated keratinocytes. Sci Rep 5:11373

Yu L, Yang Y, Hou J, Zhai C, Song Y, Zhang Z, Qiu L, Jia X (2015a) MicroRNA-144 affects radiotherapy sensitivity by promoting proliferation, migration and invasion of breast cancer cells. Oncol Rep 34:1845-1852

Yu Q, Li B, Li P, Shi Z, Vaughn A, Zhu L, Fu S (2015b) Plasma microRNAs to predict the response of radiotherapy in esophageal squamous cell carcinoma patients. American journal of translational research 7:2060-2071
Zhai G, Li G, Xu B, Jia T, Sun Y, Zheng J, Li J (2016) miRNA-148b regulates radioresistance in non-small lung cancer cells via regulation of MutL homologue 1. Biosci Rep 36

Zhang Q, Zhang S (2017) miR-214 promotes radioresistance in human ovarian cancer cells by targeting PETN. Bioscience Reports 37

Zhang J, Zhang C, Hu L, He Y, Shi Z, Tang S, Chen Y (2015a) Abnormal expression of miR-21 and miR-95 in cancer stem-like cells is associated with radioresistance of lung cancer. Cancer Invest 33:165171

Zhang X, Shi H, Lin S, Ba M, Cui S (2015b) MicroRNA-216a enhances the radiosensitivity of pancreatic cancer cells by inhibiting beclin-1mediated autophagy. Oncol Rep 34:1557-1564

Zhang Y, Zheng L, Ding Y, Li Q, Wang R, Liu T, Sun Q, Yang H, Peng S, Wang W, Chen L (2015c) MiR-20a induces cell radioresistance by activating the PTEN/PI3K/Akt signaling pathway in hepatocellular carcinoma. Int J Radiat Oncol Biol Phys 92:1132-1140

Zhang YH, Wang QQ, Li H, Ye T, Gao F, Liu YC (2016) miR-124 radiosensitizes human esophageal cancer cell TE-1 by targeting CDK4. Genet Mol Res 15

Zhang Y, Zheng L, Lin S, Liu Y, Wang Y, Gao F (2017) MiR-124 enhances cell radiosensitivity by targeting PDCD6 in nasopharyngeal carcinoma. International journal of clinical and experimental pathology 10:11461-11470

Zhang Y, Chen Z, Feng L, Jiang P, Li X, Wang X (2019) Ionizing radiation-inducible microRNA-21 induces angiogenesis by directly targeting PTEN. Asian Pac J Cancer Prev 20:1587-1593

Zhao H, Cheng Y, Dong S, Du J, Gao F, Sun D, Cui J, Ni J, Cai J (2017) Down regulation of miR-143 promotes radiation - induced thymic lymphoma by targeting B7H1. Toxicol Lett 280:116-124

Zhen L, Li J, Zhang M, Yang K (2016) MiR-10b decreases sensitivity of glioblastoma cells to radiation by targeting AKT. J Biol Res (Thessalon) 23:14

Zheng CP, Han L, Hou WJ, Tang J, Wen YH, Fu R, Wang YJ, Wen WP (2015a) MicroRNA-9 suppresses the sensitivity of CNE2 cells to ultraviolet radiation. Mol Med Rep 12:2367-2373

Zheng L, Zhang Y, Liu Y, Zhou M, Lu Y, Yuan L, Zhang C, Hong M, Wang S, Li X (2015b) MiR-106b induces cell radioresistance via the PTEN/PI3K/AKT pathways and p21 in colorectal cancer. J Transl Med 13:252

Zheng J, Dai Y, Yang Z, Yang L, Peng Z, Meng R, Xiong Y, He J (2016) Ezrin-radixin-moesin-binding phosphoprotein-50 regulates EGFinduced AKT activation through interaction with EGFR and PTEN. Oncol Rep 35:530-537

Zheng R, Liu Y, Zhang X, Zhao P, Deng Q (2017) miRNA-200c enhances radiosensitivity of esophageal cancer by cell cycle arrest and targeting P21. Biomedicine \& Pharmacotherapy 90:517-523

Zhou L, Bai H, Deng C, Wang C, Xu R, Shao S (2015a) MicroRNA-21 is involved in X-ray irradiation resistance in K562 leukaemia cells. Hematology 20:343-348

Zhou Y, Zhang L, Fan J, Jia R, Song X, Xu X, Dai L, Zhuang A, Ge S, Fan $X$ (2015b) Let-7b overexpression leads to increased radiosensitivity of uveal melanoma cells. Melanoma Res 25:119-126

Zhu H, Zhu X, Cheng G, Zhou M, Lou W (2015) Downregulation of microRNA-21 enhances radiosensitivity in nasopharyngeal carcinoma. Experimental and Therapeutic Medicine 9:2185-2189

Publisher's note Springer Nature remains neutral with regard to jurisdictional claims in published maps and institutional affiliations. 